\title{
$>$ Hannah Arendt \& João Guimarães Rosa: Reflexões sobre a amizade e a educação
}

\author{
> Hannah Arendt \& João Guimarães Rosa: \\ Reflections on friendship and education
}

\section{por Carlos Eduardo Gomes Nascimento}

Mestre em Educação pela Universidade Federal da Bahia. E-mail: carlos_gomes02@hotmail.com. ORCID: 0000-0001-8349-3493.

\section{Resumo}

O ensaio debate a relação entre a concepção da amizade (philia) e a noção de educação no pensamento de Hannah Arendt e as histórias do sertão de João Guimarães Rosa. Arendt concebe a educação como um espaço de mediação e cuidado entre as gerações, em que as mais antigas têm a responsabilidade de introduzir as gerações mais novas no mundo. Considerando essa perspectiva, aborda-se a possibilidade de pensar a ideia da educação que narre histórias que criem um laço de amizade entre gerações no mundo. Mediante o pensamento de Hannah Arendt e a narrativa do sertão de Guimarães Rosa reflete-se uma educação como amizade na responsabilidade que os educadores têm em transmitir um legado, herança cultural, às futuras gerações.

Palavras-chave: Educação. Amizade. Hannah Arendt. Guimarães Rosa.

\begin{abstract}
The essay discusses the relationship between the conception of friendship (philia), and the notion of education in the thought of Hannah Arendt and the stories of the backlands by João Guimarães Rosa. Arendt conceives education as a space of mediation and care between generations, in which the elderly have the responsibility to present the new generations to the world. Considering this perspective, it is possible to think about the idea of education that tells stories, that creates a bond of friendship between generations in the world. Through the thinking of Hannah Arendt and the narrative of the backlands of Guimarães Rosa, an education as friendship is reflected in the responsibility that educators have in transmitting a legacy, a cultural heritage, to future generations.
\end{abstract}

Keywords: Education. Friendship. Hannah Arendt. Guimarães Rosa. 


\section{A amizade, onde ela anda?}

O que "resta é a língua", 1 responde Hannah Arendt em entrevista a Günter Gaus, em 28 de outubro de 1964, acerca da sua experiência pessoal e da sua relação com a Alemanha após o nazismo. Para a autora, a língua materna guarda o sentimento de pertencimento que vincula os homens à memória, família, história e cultura. Em uma Alemanha sob os escombros do totalitarismo, a língua materna foi o que restou. Mesmo Arendt, na condição de apátrida, a preservou conscientemente, conforme lembra: "em alemão, conheço de cor uma boa parte da poesia alemã, de alguma maneira, os poemas sempre estão ali no fundo da minha mente"2.

A língua presente nas diversas manifestações humanas relaciona-se tanto com as necessidades básicas da vida quanto com as expressões simbólicas mais complexas, como arte, literatura, filosofia e ciência. Nesse sentido, a língua é muito mais do que um conjunto de palavras, trata-se de "um dos mais importantes processos de iniciação de uma criança no mundo cultural e social"3.

A criança apreende a vivacidade da língua inicialmente através das experiências familiares e culturais de que participa em seu contexto social. Posteriormente, as marcas das experiências humanas podem ser apreendidas por meio das narrativas encontradas em pergaminhos, livros, ou na memória em versos dos poetas, na canção dos bardos e trovadores, nos repentes dos violeiros do sertão, na "oratura"4 dos griots, contadores de histórias africanos. Muitas crianças ainda acessam as expressões literárias reveladas nos contadores de histórias que, de boca em boca, difundem as experiências humanas de vozes distantes no tempo. Outras crianças, mediadas pelos saberes escolares, conhecem

\footnotetext{
${ }^{1}$ Hannah Arendt, Compreender: formação, exílio e totalitarismo, 2007, p.42.

2 Ibidem, p. 42.

3 José Sérgio Fonseca de Carvalho, Reflexões sobre a educação, formação e esfera pública, 2013, p. 111.

4 "Oratura" é um conceito introduzido pelo linguista ugandense, Pio Zirimu, para se referir a textos orais na tradição dos povos africanos (SCHIPPER, 2006, p. 12).
} 
o trabalho dos escritores, poesias, romances, contos, crônicas, entre outros gêneros.

Assim, a literatura marca os passos das crianças e dos jovens em direção ao encontro com um mundo mais antigo, o que torna a literatura fundamental no contexto escolar. A leitura de uma obra literária exige mais do que a decifração dos caracteres e das palavras ou a capacidade de recontar uma sucessão de eventos. A escola deve buscar o desenvolvimento de certo discernimento literário para se sensibilizar com o tema abordado para se abrir à experiência estética evocada pelo texto. ${ }^{5}$

Na escola, ao apresentar a herança compartilhada em histórias, os adultos fazem um convite às novas gerações para compreender e pensar o mundo juntos. Tal convite constitui um testamento de gerações passadas às futuras gerações. A transmissão dessa herança é um desafio para os profissionais da educação e para as crianças e os jovens. Sem isso, os seres humanos ficam desterrados do seu próprio mundo. De acordo com Arendt:

Sem testamento ou, resolvendo a metáfora, sem tradição - que selecione e nomeie, que transmita e preserve, que indique onde se encontram os tesouros e qual o seu valor - parece não haver nenhuma continuidade consciente no tempo, e portanto, humanamente falando, nem passado nem futuro, mas tão-somente a sempiterna mudança do mundo e o ciclo biológico das criaturas que nele vivem. $O$ tesouro foi assim perdido, não mercê de circunstâncias históricas e da adversidade da realidade, mas por nenhuma tradição ter previsto seu aparecimento ou sua realidade; por nenhum testamento o haver legado ao futuro. ${ }^{6}$

Apesar do rompimento dos fios da tradição, Arendt assevera que tal acontecimento "não acarreta necessariamente a perda da capacidade humana de constituir, preservar e cuidar de um mundo que nos pode sobreviver e permanecer um lugar adequado à vida para os que vêm após". ${ }^{7}$ No ensaio A crise

\footnotetext{
${ }^{5}$ José Sérgio Fonseca de Carvalho, Reflexões sobre a educação, formação e esfera pública, 2013, p. 209.

${ }^{6}$ Hannah Arendt, Entre o passado e o futuro, 2011, p. 31.

${ }^{7}$ Ibidem, p. 132.
} 
na educação (2011), Arendt pensa a educação considerando o contexto atual de ruptura da tradição e do fim da autoridade. Conforme a autora:

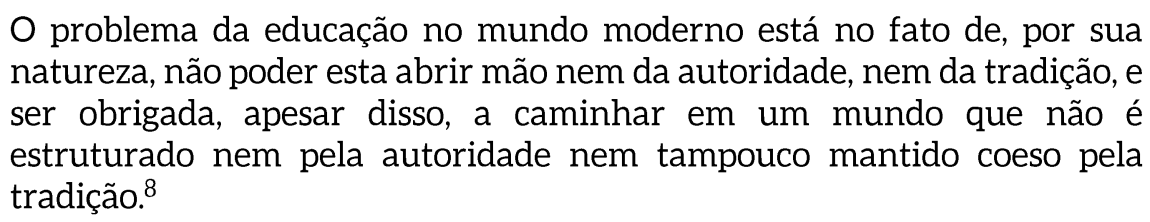

Problema extremamente difícil, a crise na educação reflete a emergência de uma crise mais ampla, uma crise em face a tudo o que é passado, por conta da perda da autoridade e da quebra dos fios da tradição. Desta maneira, Arendt argumenta que a educação não constitui um problema restrito aos profissionais da educação, nem meramente metodológico "de saber por que Joãozinho não sabe ler". ${ }^{9}$ Assim, a crise na educação assume contornos de uma questão que diz respeito a todos os seres humanos, os quais vivem sob o abrigo de um mundo comum. Apesar dessa crise face ao passado, as gerações mais velhas não podem abrir mão da responsabilidade de apresentar o mundo às novas gerações.

Para Arendt (2011), a educação constitui-se como uma forma de relacionar as novas gerações com o passado, através das experiências fundantes na história do mundo comum. Assim, mesmo diante da ruptura da tradição, caberia à educação buscar novas formas de se relacionar com o passado e estabelecer vínculos de pertencimento com o mundo comum, pois os adultos são responsáveis pelo cuidado com as novas gerações e pela apresentação de mundo mais antigo para as crianças e os jovens, recém-chegados a este mundo.

Considerando essa perspectiva, ainda é possível pensar as experiências do passado mesmo sem a segurança de um "corrimão. ${ }^{10}$ A metáfora utilizada por Arendt busca compreender quais rumos podemos seguir após a perda das linhas de orientação dadas pela tradição. Quando a educação apresenta aos novos o mundo culturalmente herdado, há uma abertura para a permanente

\footnotetext{
${ }^{8}$ Hannah Arendt, Entre o passado e o futuro, 2011, p. 245.

${ }^{9}$ Ibidem, p. 222.

${ }^{10}$ Idem. Sobre Hannah Arendt. Revista Inquietude, 2010, p.136.
} 
reconciliação com o passado, possibilitando a esperança do surgimento do novo. Assim lembra Almeida:

\begin{abstract}
Reconciliar-se com o mundo não é aceitar nem conformar-se com o que passou, mas significa que temos de entrar em acordo com este espaço comum do qual dependemos e que depende de nós. Talvez haja coisas que não podemos perdoar, mas elas não devem, em princípio, nos fazer abrir mão da possibilidade de criar e preservar o lugar da convivência. Pensando-o podemos atribuir-lhe algum sentido. É a tentativa de compreender os acontecimentos no mundo que nos ajuda a lidar com o ocorrido de modo que não destrua a possibilidade de continuarmos convivendo. ${ }^{11}$
\end{abstract}

A educação passa pelo reconhecimento de que todos os seres humanos possuem o direito de pertencer ao espaço-entre, o mundo humano plural. Para realizar sua tarefa, a educação deve acolher a singularidade presente em cada nova criança, que aqui aporta semelhante a um estrangeiro, cuja introdução ao mundo humano permite que se sinta herdeira do espaço de convivência comum. É assim que a educação proporciona o sentimento de pertença ao mundo, permitindo que as crianças e jovens se sintam em casa.

As novas gerações podem criar laços de pertencimento através de histórias que são contadas por gerações mais velhas. Contar histórias de experiências humanas passadas de um mundo comum demonstra o cuidado e a responsabilidade que uma geração mais velha possui com a geração mais nova. Quando professores contam histórias às crianças, a fim de manter viva a tessitura do compreender e pensar sobre as experiências humanas, também possibilitam a renovação do mundo pela palavra. Na escola, a literatura representa uma abertura para um mundo de experiências que conectam os estudantes ao passado e possibilitam o encontro com a própria singularidade, 0 desenvolvimento da autonomia, do pensar e do criar no mundo comum. Conforme observa Carvalho:

O sentido formativo da leitura de obras literárias, como as de Machado de Assis ou Guimarães Rosa, não se reduz a eventuais tarefas escolares de natureza estritamente cognitiva como a identificação e a compreensão de

\footnotetext{
${ }^{11}$ Vanessa Almeida, Educação em Hannah Arendt: Entre o mundo deserto e o amor ao mundo, 2011, p. 199.
} 
traços estilísticos. Sua presença no currículo se justifica, sobretudo, por seu potencial de se tornarem experiências simbólicas para quem as lê, ou seja, por sua capacidade de afetar um sujeito, de transformar sua visão de mundo, de influenciar a forma pela qual ele se relaciona consigo mesmo e com aqueles com quem compartilha o mundo. ${ }^{12}$

Conforme apresentado no artigo A crise na educação, escrito em 1958, para Arendt (2011), a escola não é o espaço do político por excelência, mas uma dimensão pré-política. Na escola, de acordo com Arendt, ocorre a transição da criança do âmbito familiar e privado para o mundo. Segundo Arendt, "a criança é introduzida ao mundo pela primeira vez através da escola". ${ }^{13}$ No âmbito privado da família, os pais são os principais responsáveis pelo cuidado com a vida dos filhos e essa transição da família para o mundo é feita na escola, porém isso não quer dizer que a escola seja o mundo público. Arendt explica que "a escola não é de modo algum o mundo e não deve fingir sê-lo, ela é, em vez disso, a instituição que interpomos entre o domínio do lar e o mundo com o fito de fazer com que seja possível a transição, de alguma forma, da família para o mundo". ${ }^{14}$

A escola não é o próprio espaço público, mas é um âmbito pré-político. ${ }^{15}$ Isto não significa dizer que a escola seja uma preparação stricto sensu para o mundo público. A escola exerce sua função na formação humana, na medida em que as crianças e os jovens podem compreender e pensar sobre as experiências comuns. Quando adultos, adentram em igualdade de condições o mundo público pelo exercício da cidadania.

Arendt é muito enfática ao criticar o pragmatismo pedagógico do modelo progressivo nos Estados Unidos. Segundo a autora, esta proposta apoiava-se numa suposta autonomia das crianças: "existe um mundo da criança e uma sociedade formada entre crianças, autônomos e que se deve, na medida do possível, permitir que elas governem. Adultos aí estão apenas para auxiliar". 16

\footnotetext{
12 José Sérgio Fonseca de Carvalho, Educação, uma herança sem testamento: diálogos com o pensamento de Hannah Arendt, 2017, p. 52.

${ }^{13}$ Hannah Arendt, Entre o passado e o futuro, 2011, p. 238.

${ }^{14}$ Ibidem, p. 238.

${ }^{15}$ Ibidem, p. 240.

${ }^{16}$ Ibidem, p. 231.
} 
Nessa perspectiva, criticada por Arendt, as crianças se autogovernariam, imitando o mundo político dos adultos, porém sem o amadurecimento para lidar com princípios políticos. As crianças estariam "jogadas a si mesmas, ou entregues à tirania de seu próprio grupo [...] por serem crianças, não podem argumentar e não podem escapar para nenhum outro mundo por lhes ter sido barrado o mundo dos adultos" ${ }^{17}$ De acordo com Almeida:

Arendt salienta, portanto, o perigo de aplicar indistintamente conceitos políticos de 'democracia' ou 'autonomia' ao âmbito da educação. Princípios políticos e educativos não são idênticos, mesmo que tanto a política como a educação se preocupem com o mundo comum. ${ }^{18}$

Diante do exposto, não se deve confundir o ato de introduzir as crianças no mundo, que é comum, com a ação política entre os adultos. Na perspectiva de Arendt, cabe aos adultos e aos professores, em igualdade, a decisão de apresentar o mundo e definir os rumos da educação, em favor do cuidado com as futuras gerações.

\section{Amizade (philia) em Guimarães Rosa e Hannah Arendt}

A narrativa do romance Grande Sertão: Veredas, de Guimarães Rosa, traz as memórias de um sertanejo, personagem Riobaldo, ora jagunço, ora professor, o qual conta a sua história de experiências vividas para compreender se há algum sentido em um mundo caracterizado pela ambiguidade das coisas e sentimentos humanos. Nesta história, o sertão é do tamanho do mundo; está simbolizado por diversos planos de ambiguidades e de fusão dos contrários, representados tanto no desejo de amar Diadorim, a mulher-homem, quanto no conflito existencial do par Deus e o Diabo, entre o estilo erudito e popular, arcaico e moderno. Este é um mundo "que nos suspende entre o ser e o não ser para nos sugerir formas mais

\footnotetext{
${ }^{17}$ Hannah Arendt, Entre o passado e o futuro, 2011, p. 231.

${ }^{18}$ Vanessa Almeida, Educação em Hannah Arendt: Entre o mundo deserto e o amor ao mundo, 2011, 123.
} 
ricas de integração do ser". ${ }^{19}$

Com efeito, essas histórias constituem uma poética do mundo compartilhado entre as gerações, contam sobre personagens em um interstício existencial e revelam um mundo em ambiguidade, isto é, um mundo sempre a se fazer. O "bardo", no budismo tibetano, constitui o estágio intermediário entre a morte e o renascimento, simbolizando o "espaço entre", uma terceira margem, onde se conta uma história. Rio-bardo conta um mundo que corre como um rio em devir e transmite em altos brados um mundo reclamando ser ouvido, pois mesmo distantes de suas margens, o grito das águas chega, a fim de apontar que sempre há uma disposição para a travessia daqueles abertos a ouvir. As histórias são a voz do mundo, assim conta Riobaldo, o bardo do sertão, narrador que ocupa o "espaço entre", capaz de contar uma história: "Digo: o real não está na saída nem na chegada: ele se dispõe para a gente é no meio da travessia". ${ }^{20}$

No artigo A outra margem da narrativa: Hannah Arendt e João Guimarães Rosa, Heloisa Maria Murgel Starling destaca essa relação entre o processo narrativo de Arendt e o de Guimarães Rosa:

Na tentativa de caminhar para trás no tempo e chamar de volta ao coração 'o desamargado dos sonhos' própria a cada narrador, história, mito e poesia [....] registram embricamentos possíveis entre as fronteiras do histórico e do literário, ainda produzem as condições para um esforço retrospectivo da imaginação criativa, baseada no trabalho da memória, que tem o mundo como horizonte, as imagens como técnica de deciframento e a linguagem como mediação. Nos termos definidos pelo jagunço Riobaldo Tatarana, essa tentativa de preservar a matéria de onde são feitas todas as histórias, deixando falar a memória quando tudo o mais parece ter emudecido era, na verdade, seu principal compromisso para com o mundo, ainda que velho, repassado de melancolia, praticamente já se tenha retirado dele. ${ }^{21}$

Ao contar histórias, afiança-se um território constituído por memórias em que os seres humanos de diversas gerações se movem e podem criar laços não somente entre eles, mas também com o mundo do presente, espaço de constantes

\footnotetext{
${ }^{19}$ Antônio Candido, Tese e antítese: ensaios, 2000, p. 134.

20 João Guimarães Rosa, Grande Sertão: Veredas, 2001, p. 80.

${ }^{21}$ Heloisa Maria Murgel Starling, A outra margem da narrativa: Hannah Arendt e João Guimarães Rosa, 2001, p. 253.
} 
experiências, acontecimentos e afetos que são compartilhados. Arendt lembra grandes histórias que encantam os homens, nas quais poetas e bardos os ajudavam a atingir a imortalidade: "isto porque a estória das coisas feitas sobreviveu aos atos e o que foi dito torna-se imortal se for bem dito (...). Os bardos, à maneira de Homero, endireitavam a estória com palavras mágicas para encantar os homens para sempre". ${ }^{22}$ As histórias conservam a memória, fazemse presentes no exercício do imaginar aos homens; quando contadas e recontadas, trazem à lembrança experiências vivas do passado, criadoras de uma promessa de aliança entre as gerações. Afinal, "a presença de outros que veem o que vemos e ouvem o que ouvimos garante-nos a realidade do mundo e de nós mesmos". ${ }^{23}$

Nas histórias do sertão brasileiro, a amizade é um valor que transcende as dimensões das veredas no tempo e no espaço. Diversas gerações cruzam-se no universo sertanejo entre as vendetas dos jagunços. Nesse sistema, em que o acerto de contas e a violência são a prerrogativa da existência, era de se pensar que a amizade fosse um tema distante, ou que a amizade entre os seres humanos se convergiria para interesses particulares, dominados pelo o braço e o aço. Mas a amizade no sertão aparece como marca da existência e permanência humana entre os buritizais e os chapadões. A amizade gera um movimento no sertão de Guimarães Rosa. A capacidade humana de escolher tem seus sentidos revelados na amizade. Essa escolha significa dizer ao mundo com quem se deseja passar o desafio das horas; aqueles com quem se quer conviver, dialogar, agir e, juntos, construir uma história comum. Riobaldo, o narrador de Grande Sertão: Veredas, revela-nos os sentidos da amizade no sertão:

Amigo? Aí foi isso que eu entendi? Ah, não; amigo, para mim, é diferente. Não é um ajuste de um dar serviço ao outro, e receber, e saírem por este mundo, barganhando ajudas, ainda que sendo com o fazer a injustiça aos demais. Amigo, para mim, é só isto: é a pessoa com quem a gente gosta de conversar, do igual o igual, desarmado. $O$ de que tira prazer de estar próximo. Só isto; quase; e todos sacrifícios. Ou - amigo - é que a gente seja, mas sem precisar de saber o por quê é que é. Amigo meu era Diadorim; era

\footnotetext{
${ }^{22}$ Hannah Arendt, A condição humana, 2016a, p. 152.

${ }^{23}$ Ibidem, p. 62.
} 
Fafafa; o Alaripe; Sesfrêdo. ${ }^{24}$

Riobaldo não queria a amizade do jagunço Hermogenes, "homem que tirava seu prazer do medo dos outros, do sofrimento dos outros". ${ }^{25}$ Hermogenes por todo custo tentava se aproximar de Riobaldo, fazendo elogios e dando-lhe presentes, mas Riobaldo sempre buscava se esquivar dele. Conta Riobaldo: "Aquele Hermogenes me fazia agrados, demo que ele gostava de mim". ${ }^{26} \mathrm{~A}$ amizade não se faz pela barganha por conquista de vantagens, pelo toma-lá-dácá, pensar desta maneira é se opor ao sentido de amizade. As ações de Hermogenes, a representação do falseamento da amizade, que hoje oferece, mas que amanhã cobra pelo sangue, essa é uma oposição ao sentido da amizade que vagueia no mundo, tentando seduzir, puxar para seu caminho. As investidas de Hermogenes para conquistar a amizade de Riobaldo parecem ser uma das faces do desalento que toma alguns espíritos humanos na modernidade. A sedução do tirar vantagem em tudo afasta os seres humanos uns dos outros e também da constituição de uma história comum. Para a satisfação de desejos particulares, qualquer gesto deve ser acompanhado de alguma recompensa ou benesse.

A amizade revela-se publicamente face a face, evidenciada por uma escolha de com quem se quer conviver. Para além da amizade entre duas pessoas, a amizade é revelada no reconhecimento de uma história que constitui o mundo comum, compartilhado por todos os seres humanos. Desta maneira, a destruição do outro, de seu passado e de sua história, é a inimizade ao mundo.

Nessa perspectiva, a amizade tem como sentido o compartilhamento entre os seres humanos que querem estar juntos e realizar através de palavras e ações um mundo comum, no qual podem conviver. A amizade aparece na vida pública, torna-se visível entre as pessoas, preservando o mundo comum. No trecho intitulado "Diálogo entre amigos" do texto Filosofia e Política, escreve Arendt:

A amizade consiste, em grande parte, na verdade, nesse falar sobre algo

\footnotetext{
24 João Guimarães Rosa, Grande Sertão: Veredas, 2001, p. 196

25 João Guimarães Rosa, Grande Sertão: Veredas, 2001, p. 197.

${ }^{26}$ Ibidem, p. 205.
} 
que os amigos têm em comum. Ao falarem sobre o que têm entre si, isso se torna muito mais comum a eles. Não só o assunto ganha sua articulação específica, mas desenvolve-se, expande-se e finalmente, no decorrer do tempo e da vida, começa a constituir um pequeno mundo particular, que é compartilhado na amizade. ${ }^{27}$

Diversos sentidos foram explorados na história do pensamento filosófico para o significado da amizade, principalmente, no contexto sobre o questionamento da ética e a política. A amizade (philia) compõe as raízes da própria palavra filosofia. Segundo conta Diógenes Laértio, ${ }^{28}$ Pitágoras foi o primeiro a usar o termo e a chamar-se de filósofo: "amigo da sabedoria". O tema da amizade está presente na obra de Arendt, que não se encarava como filósofa, mas estava em busca de outros sentidos para compreender e compartilhar o seu pensamento com seus amigos. Conforme lembra Young-Bruehl: "Arendt era fluente na linguagem da amizade", ${ }^{29}$ pois a amizade era "o centro de sua vida".

A amizade, na obra de Hannah Arendt, coloca-se enquanto uma escolha de estar junto aos outros no espaço comum de realizações, assim como Riobaldo tentou agir no sertão. Lembra Arendt que a ação "pode ser estimulada pela presença de outros a cuja companhia possamos desejar nos juntar, mas nunca é condicionada por eles; seu impulso surge do começo que veio ao mundo quando nascemos e ao qual respondemos quando começamos algo novo por nossa própria iniciativa". ${ }^{30} \mathrm{~A}$ amizade é escolha daqueles com quem se quer conviver e compartilhar experiências no mundo, isto é, a escolha dos nossos amigos. Estar entre amigos é ser partícipe de uma pluralidade e reconhecer a existência da singularidade de quem se quer dialogar e estar junto na renovação de um mundo comum.

A amizade no sentido arendtiano aparece quando os seres humanos se associam publicamente, através da manifestação de suas palavras e atos. $\mathrm{Na}$ amizade, as pessoas estão entre iguais. Assim, no texto Filosofia e política, diz

\footnotetext{
${ }^{27}$ Hannah Arendt, A dignidade na política, 2006, p. 98.

${ }^{28}$ Diógenes Laértio, Vidas e doutrinas dos filósofos ilustres, 2008, p. 15.

${ }^{29}$ Elizabeth Young-Bruehl, Hannah Arendt, por amor ao mundo, 1997, p. 13.

${ }^{30}$ Hannah Arendt, A condição humana, 2016a, p. 219.
} 
Arendt: "A igualação na amizade não significa, naturalmente, que os amigos se tornem os mesmos, ou sejam iguais entre si, mas antes, que se tornem parceiros iguais em um mundo comum - que, juntos, constituam uma comunidade". ${ }^{31}$ Os mais novos, uma geração ainda em formação, buscam seu lugar na construção do mundo comum. Depois de introduzidos através da educação, poderão ser tão responsáveis quanto seus antepassados, criadores de um mundo comum. No curso do tempo, a amizade estabelece laços entre as gerações, que se igualam enquanto criadoras de um mundo comum. Para Arendt, a educação não é o espaço público de decisões, mas território no qual as diversas gerações podem se encontrar para estabelecer vínculos.

Na obra de Arendt, o tema da amizade aparece em alguns textos enquanto ligação entre os seres humanos na construção e preservação do espaço público que permite conviver em pluralidade. Os textos de Arendt que fazem referência à amizade foram publicados no final da década de 1950, em datas próximas a $\mathrm{A}$ crise na educação, como por exemplo: "Sobre a humanidade em tempos sombrios: reflexões sobre Lessing", ${ }^{32}$ resultado do discurso proferido em 1959, por ocasião da aceitação do Prêmio Lessing da Cidade Livre de Hamburgo, em homenagem ao poeta alemão do século XVIII, Gotthold Ephraim Lessing; o tema da amizade também é abordado no seu livro A condição humana, publicado em 1958.

Arendt estabelece uma relação entre a amizade e o contar histórias quando analisa a leitura da peça Nathan, o sábio, de Lessing, drama clássico sobre a temática da amizade, em que o comprometimento com o mundo se dá pelos laços criados entre amigos. A amizade, na perspectiva de Arendt, não se volta para o sentimento da intimidade, mas para um sentido de um mundo comum compartilhado entre os seres humanos, "a amizade não é intimamente pessoal, mas faz exigências políticas e preserva a referência ao mundo". ${ }^{33}$ Em Nathan, o sábio, Lessing conta a história do encontro de três homens com culturas

\footnotetext{
${ }^{31}$ Hannah Arendt, A Dignidade na política, 2006, p. 99.

${ }^{32}$ Idem, Homens em tempos sombrios, 2015.

${ }^{33}$ Ibidem, p. 34.
} 
diferentes: Nathan, Saladino e o Templário, representantes cada um de uma cultura e religião, respectivamente, a judaica, a islâmica e a cristã. À primeira vista, a amizade entre as personagens parece não ser possível, no entanto Lessing rejeitava conscientemente qualquer doutrina ou princípio que pudesse barrar a possibilidade de não haver amizade entre os homens. ${ }^{34}$ Nathan, o sábio mostra-se como uma força em direção à amizade, nos seus versos a estabelece como laço comum entre os homens, apesar das culturas diversas e dos conflitos. Lessing ${ }^{35}$ conta que Saladino, o sultão do Oriente, escuta do povo que um viajante havia chegado à região: Nathan, considerado um dos homens mais sábios. Curioso, o sultão o chama em seu palácio para lhe fazer uma pergunta difícil: qual entre as três religiões, judaísmo, islamismo ou cristianismo, seria a verdadeira? Nathan não reluta e conta uma história ao sultão: um pai amava muito seus filhos. Ele tinha um anel cuja força maravilhosa tornava seu possuidor amado por Deus e pelos homens. Havia recebido esse anel de seu próprio pai, transmitido de geração a geração. Em seu leito de morte, o pai ordena a fabricação de anéis semelhantes ao seu. Ao receber os anéis, já não sabia mais reconhecer o seu anel entre os demais. No entanto, antes de morrer, entregou a cada um dos amados filhos um anel. Após sua morte, seus filhos entram em conflito sobre quem seria o possuidor do anel verdadeiro. Para tentar pacificar os ânimos dos irmãos, um juiz observa:

\author{
Vossos anéis não são verdadeiros \\ Nenhum dos três. \\ O verdadeiro anel \\ Provavelmente se perdeu (...) \\ Se cada um tem o anel de seu pai: \\ Cada um acredite \\ Que o seu é verdadeiro
}

\footnotetext{
${ }^{34}$ Hannah Arendt, Homens em tempos sombrios, 2015, p. 35.

${ }^{35}$ Gotthold Ephraim Lessing,Três peças, 2015.
} 
É possível até,

Que o pai não quisesse mais tolerar

A tirania do único anel em sua casa!36

Estar em um mundo junto com os outros e compartilhá-lo com as mais diferentes gerações não deve ser perdido. Cada geração é possuidora de um anel, esse anel estabelece laços de amizade entre aqueles que construíram esse mundo e que são herdeiros em cuidar de uma casa comum entre todos os seres humanos. A amizade surge como esse reconhecimento da diversidade humana, dada na pluralidade pelas ações e palavras, que se realizam no mundo. Nesse tocante sobre a amizade, ao analisar a peça Nathan, o sábio de Lessing, escreve Arendt:

o anel verdadeiro, se é que algum dia existira, se perdera; [Lessing] estava contente em consideração pelo número infinito de opiniões que surgem quando os homens discutem os assuntos deste mundo. Se o verdadeiro anel existisse, significaria o fim do discurso, e portanto da amizade, e portanto da humanidade. ${ }^{37}$

Na história de Lessing, durante diálogo entre Nathan e o jovem Templário, este mostra-se desconfiado. Então, Nathan sensibiliza o seu dialogante para os sentidos da amizade entre os seres humanos. Lembra Lessing, através da voz de Nathan, que:

\author{
Ahá! Vós não sabeis \\ Com quanto maior insistência \\ Me aproximei de vós agora. \\ Vinde, nós precisamos, \\ Precisamos ser amigos! \\ Desprezai meu povo \\ O quanto quiserdes,
}

Nós não escolhemos, ambos,

O nosso povo. E somos nós o nosso povo?

\footnotetext{
${ }^{36}$ Ibidem, p. 351.

${ }^{37}$ Hannah Arendt, Homens em tempos sombrios, 2015, p. 35.
} 
O que é povo, afinal?

Cristão e judeu

São antes cristão e judeu,

Do que ser humanos?

Ah! Se eu tivesse

Encontrado em vós

Mais um ao qual basta

Se chamar de homem! ${ }^{38}$

Observa-se em Lessing que, mesmo diante das maiores adversidades, os seres humanos podem cultivar a amizade. Nesse sentido, Arendt, apesar de não adotar o humanismo de Lessing, inspira-se na história de Nathan para refletir sobre a amizade: as pessoas não apenas podem ser amigas, mas também compartilham um mundo duradouro, com outros seres singulares. Este princípio da amizade emerge como vínculo entre as pessoas, atravessa a temporalidade, pode ser traduzido pela comunicação de atos e palavras, através de histórias que conectam as gerações humanas. Como supracitado, A condição humana foi publicado por Hannah Arendt na mesma época que o discurso sobre Lessing (respectivamente, 1958 e 1959). Nessa obra, o tema da amizade aparece como escolha de cada indivíduo, mas também no domínio público, através de palavras e atos, como criação do vínculo entre os seres humanos, instituindo uma rede de relações. Em A condição humana, Arendt estabelece uma tensão entre a amizade e o amor. A autora faz considerações acerca do domínio do privado e do público. Para ela, a experiência humana do amor encontra-se no domínio do privado. Assim, escreve Arendt:

o amor, por exemplo, em contraposição à amizade, morre ou, antes, se extingue assim que é trazido a público. Dada a sua inerente nãomundanidade, o amor só pode ser falsificado e pervertido quando utilizado para fins políticos, como a transformação ou salvação do mundo. ${ }^{39}$

\footnotetext{
${ }^{38}$ Gotthold Ephraim Lessing,Três peças, 2015, p. 351.
}

${ }^{39}$ Hannah Arendt, A condição humana, 2016a, p. 63. 
Arendt considera que a amizade, no entanto, aparece no mundo público. Quando se remete à tradição política da Grécia antiga, advinda do pensamento de Aristóteles, a philia politique, ${ }^{40}$ Arendt aponta que a amizade não deve ser confundida com recantos de intimidade entre dois indivíduos, mas aparece ao mundo público, através de ações e palavras, desde que haja ligação entre as pessoas. Para Arendt:

\begin{abstract}
Quando, por exemplo, lemos em Aristóteles que a philia, a amizade entre os cidadãos, é um dos requisitos fundamentais para o bem-estar da Cidade, tendemos a achar que ele se referia apenas à ausência de facções e guerra civil. Mas, para os gregos, a essência da amizade consistia no discurso. Sustentavam que apenas o intercâmbio constante de conversas unia os cidadãos numa polis. No discurso, tornavam-se manifestas a importância política da amizade e a qualidade humana própria a ela. ${ }^{41}$
\end{abstract}

Com efeito, a amizade, na perspectiva de Arendt, traz em seu bojo uma concepção pública de uma tradição política grega e romana, distinta da ideia de amizade na modernidade em que "estamos habituados a ver a amizade como um fenômeno da intimidade [...] a atitude básica do indivíduo moderno que, em sua alienação do mundo, realmente só pode se revelar na privacidade e intimidade dos encontros pessoais". ${ }^{42}$ A experiência da convivência humana no mundo configura a amizade na concepção da tradição da Grécia clássica, observada por Arendt. Nas palavras de Sócrates: "Uma vida sem exame não merece ser vivida"; ${ }^{43}$ parafraseando-as, Arendt recompõe a perspectiva socrática na polis grega: "os antigos consideravam os amigos indispensáveis à vida humana e na verdade uma vida sem amigos não é digna realmente de ser vivida". ${ }^{4}$

Além dessa perspectiva vinculada ao mundo público, Arendt em A Vida do Espírito, ${ }^{45}$ discute outra possibilidade para o tema da amizade: o que acontecia com Sócrates, quando ele se retirava do mundo público para pensar? Para Arendt, Sócrates enuncia, em seu modo de vida, que além de interagir com a

\footnotetext{
${ }^{40}$ Idem, Entre o passado e o futuro, 2011, p. 301.

${ }^{41}$ Idem, Homens em tempos sombrios, 2015. p. 33.

${ }^{42}$ Hannah Arendt, Homens em tempos sombrios, 2015, p. 33.

${ }^{43}$ Platão, Apologia de Sócrates, 1972.

${ }^{44}$ Hannah Arendt, op. cit., 2015. p. 32.

${ }^{45}$ Hannah Arendt, A Vida do Espírito, 2016b.
} 
cidade, também é indispensável um exercício do diálogo consigo mesmo, experiência condutora para a amizade. Embora as nuances sobre a problemática da concepção do pensar em Hannah Arendt não tenham constituído os objetivos da presente pesquisa, é importante ressaltar essa questão porque neste ponto Arendt estabelece uma relação entre o pensar e a amizade, através da existência de um diálogo consigo mesmo. Arendt retoma a metáfora socrática para o exercício do pensar, encontrada no diálogo Hípias Maior, de Platão: Sócrates lembra que após proferir algum discurso na ágora, ao voltar para casa, ele sempre se faz acompanhar de um sujeito, que não o deixa em sossego:

não há nada mais admirável do que ser alguém capaz de proferir um discurso bem feito, no tribunal ou em qualquer outra reunião: imediatamente passo a ouvir as piores invectivas por parte dos presentes, mas, em primeiro lugar, desse sujeito que outra coisa não faz senão refutar tudo o que eu digo. Acontece, também, que somos parentes próximos e moramos juntos. Sempre que eu chego a casa e ele me ouve discorrer dessa maneira, pergunta-me se não me envergonho de falar a respeito das belas maneiras de viver, sendo, como sou, reconhecidamente ignorante, visto não saber até mesmo o que venha a ser essa beleza. ${ }^{46}$

Esse "sujeito" questionador que acompanha Sócrates e não o deixa sossegar, nem mesmo em sua casa, trata-se, para Arendt, do "dois-em-um", isto é, a companhia de um "sujeito" questionador em seu próprio pensamento, com o qual dialogava, criando uma ideia de amizade no exercício do pensar. Nesse sentido, escreve Arendt:

Para Sócrates, a dualidade do dois-em-um significava apenas que quem quer pensar precisa tomar cuidado para que os parceiros do diálogo estejam em bons termos, para que eles sejam amigos. O parceiro que desperta novamente quando estamos alertas e sós é o único do qual nunca podemos nos livrar - exceto parando de pensar. ${ }^{47}$

Nessa perspectiva socrática sobre a amizade e o pensamento, retomada por Arendt, o pensamento não é apenas uma atividade cognitiva, mas um "diálogo entre amigos" ${ }^{48}$ No artigo Filosofia e política, Arendt aborda, também, a personagem de Sócrates a partir do diálogo com seus amigos. Nesse texto, Arendt

\footnotetext{
${ }^{46}$ Platão, Hípias, 1980.

${ }^{47}$ Hannah Arendt, A vida do espírito, 2016b, p. 210.

${ }^{48}$ Idem, A Dignidade na política, 2006, p. 98.
} 
expõe que "Sócrates parece ter acreditado que a função política do filósofo era ajudar a estabelecer esse tipo de mundo comum, construído sobre a compreensão da amizade, em que nenhum governo é necessário". ${ }^{49} \mathrm{~A}$ amizade em Arendt "se manifesta numa presteza em partilhar o mundo com outros homens". ${ }^{50}$ Essa perspectiva tem como sentido o cuidado com o mundo comum. Contudo, na modernidade, em meio ao consumo, as relações humanas foram reduzidas à intimidade: os indivíduos modernos alienaram-se do mundo e começaram a se refugiar em "si-mesmo".51 O mundo não é humano simplesmente por ser constituído por seres humanos, nem se torna humano simplesmente porque a voz humana nele ressoa. O mundo torna-se humano quando se constitui das ações e palavras. Considerando a ideia de Arendt sobre o sentido público da amizade, observa Wolfgang Heuer:

Amizade política pelo cuidado do mundo significa ser consciente da responsabilidade comum pela comunidade, definir-se como cidadão político e não como um sujeito de consumo e defender a civilização da sociedade com seus valores de liberdade e justiça e de engajar-se para a sua realização..$^{52}$

A amizade aparece no espaço público pelo cuidado com o mundo comum e na preservação da singularidade humana. A amizade cria elementos com os quais os seres humanos se relacionam entre e si e também com o mundo, espaçoentre, cujas narrativas são expressões humanas muito antigas. Nesse sentido, a amizade possui um caráter político, e é expressa publicamente entre os seres humanos. Desta maneira, a amizade constitui um exercício de reconhecimento do mundo e das decisões entre iguais na esfera pública. Segundo Arendt:

O elemento político, na amizade, reside no fato de que, no verdadeiro diálogo, cada um dos amigos pode compreender a verdade inerente à opinião do outro. Mais do que o seu amigo como pessoa, um amigo compreende como e em que articulação específica o mundo comum aparece para o outro que, como pessoa, será sempre desigual ou diferente. Esse tipo de compreensão - em que se vê o mundo (como se diz hoje um tanto trivialmente) do ponto de vista do outro - é o tipo de insight político

\footnotetext{
${ }^{49}$ Ibidem, p. 100.

${ }^{50}$ Idem, Homens em tempos sombrios, 2015, p. 34.

${ }^{51}$ Idem, A condição humana, 2016a, 2016a, p. 7.

${ }^{52}$ Wolfgang Heuer, Amizade política pelo cuidado com o mundo, 2007, p. 92.
} 
por excelência..$^{53}$

Como ouvir, compreender e pensar com o outro quando ele não está mais presente para dialogar? Com as histórias contadas, as gerações dialogam no tempo e colhem as experiências que compõem o sentido da existência humana no mundo compartilhado. Quando os seres humanos contam histórias, rememoram, optam politicamente por assegurar a conservação do mundo comum.

\section{Amizade e narrativas na educação}

Durante o refúgio do regime nazista, entre os anos de 1933 e 1940, Hannah Arendt estabeleceu um laço de amizade com Walter Benjamin (1892-1940), que segundo Arendt tinha "o dom de pensar poeticamente".${ }^{54} \mathrm{Em}$ uma de suas peças radiofônicas, "A Berlim Demoníaca", Walter Benjamin expressa a experiência de contar histórias no espaço educacional. Benjamin relata um momento da sua vida como estudante de um internato, onde professores e alunos se reuniam toda semana para ler poesia e trechos de narrativas. Benjamin descreve um de seus professores, o senhor August Halm, que gostava dos contos fantásticos de E.T.A. Hoffmann. Antes de iniciar as histórias, seu professor instigava os alunos com a seguinte provocação: "Para que alguém escreve histórias como essas? Isto eu explicarei a vocês numa próxima vez", ${ }^{55}$ só que aquele velho professor veio a falecer, deixando à eternidade sua explicação.

A reflexão deste episódio narrado por Benjamin pode vir a provocar aos educadores a refletir sobre o "para que" contar histórias aos jovens. Ao ouvir as histórias misteriosas escritas por Hoffmann e contadas pelo professor Halm, o jovem Benjamin pôde escolher e pensar com as gerações passadas. Laços de

\footnotetext{
${ }^{53}$ Hannah Arendt, A dignidade na política, 2006, p. 99.

${ }^{54}$ Idem, Homens em tempos sombrios, 2015, p. 222.

${ }^{55}$ Walter Benjamin, A hora das crianças: narrativas radiofônicas de Walter Benjamin, 2015, p. 39.
} 
amizade entre a geração de Hoffmann, Halm e Benjamin foram criados.

Como ocorre nas relações entre amigos, a escolha em querer conviver com as vozes do passado significa não apenas as ouvir, mas principalmente, as compreender, pensar junto com elas, ou mesmo discordar. Assim, estabelece-se uma convivência no tempo, traçando entre os seres no presente um caminho político através da amizade. Dessa maneira, a amizade por histórias é um modo de reencontrar o passado, recobrar a comunicação entre gerações, compreender e pensar as experiências humanas. Na educação, o encontro com as gerações passadas, com quem os professores, crianças e jovens podem também dialogar, resulta na escolha de com quem se quer aprender e pensar junto, criando uma relação de amizade.

Na sociedade do consumo e na cultura de massas, que atomiza as pessoas, a experiência do desenraizamento do passado e de um mundo comum direcionam as relações de amizade para o âmbito do individualismo. Assim, o reconhecimento da comunicação entre gerações por suas histórias deixa de estabelecer conexões. Em uma sociedade massificada, a perda do espaço-entre desagrega a partilha de interesses comuns entre as pessoas, que não se sentem, mesmo no cotidiano da vida, pertencentes a uma comunidade, muito menos a um mundo comum. Conforme anota Odílio Aguiar, no texto A amizade como amor mundi em Hannah Arendt:

É nessa sociedade massificada onde nenhuma vivência mundana pode ser experimentada que Arendt aponta a decadência da amizade e a despersonalização da vida pública. Nas sociedades massificadas, o sentido recorrente de amizade é o da partilha da intimidade ou da compaixão filantrópica. Perde-se, deste modo, o sentido original mesmo de filantropia, amor e admiração pelas coisas humanas, deturpando-a em caridade ou sentimentalismo em face da dor espetacularmente exposta. ${ }^{56}$

Sem a amizade publicamente revelada, perdem-se os laços de comunicabilidade entre as gerações, esvai-se a possibilidade de compreender a existência e construir o mundo comum através de feitos em palavras e ações. Sem

${ }^{56}$ Odílio Aguiar, A amizade como amor mundi em Hannah Arendt, 2010, p. 137. 
o amor ao mundo, não há amizade entre as gerações. Diferente do amor romântico, residente na sede privativa do obscuro coração humano, o amor ao mundo faz parte de um coração compreensivo e vincula-se ao maior legado humano: o mundo comum. Diante dessa perspectiva, considera-se que a amizade, também, é reveladora do amor ao mundo, e nesse sentido enseja a responsabilidade das gerações mais velhas com as futuras gerações, construindolhes um legado: apresentar o mundo com seus laços culturais às crianças e aos jovens. Esse legado revela-se na educação com a amizade entre as gerações, que configura um espaço comum, culturalmente herdado de gerações anteriores, com tradições, costumes e práticas. Desta maneira, pensado como revelação e princípio da amizade, o amor mundi, concepção refletida por Arendt, expressa-se no cuidado com o passado, através da educação. Segundo Arendt:

A educação é o ponto em que decidimos se amamos o mundo o bastante para assumirmos a responsabilidade por ele e, com tal gesto, salvá-lo da ruína que seria inevitável não fosse a renovação e a vinda dos novos e dos jovens. A educação é, também, onde decidimos se amamos nossas crianças o bastante para não expulsá-las de nosso mundo e abandoná-las a seus próprios recursos, e tampouco arrancar de suas mãos a oportunidade de empreender alguma coisa nova e imprevista para nós, preparando-as em vez disso com antecedência para a tarefa de renovar um mundo comum. ${ }^{57}$

Compreende-se que amar o mundo é o estado de permanente atenção sobre os nossos atos e palavras no mundo comum; é o fato de compreender que a existência e as experiências humanas são frágeis, fugazes; é a obrigação que todos os adultos, pais, professores têm em contar às crianças e aos jovens as histórias do passado, para que as novas gerações possam se sentir acolhidas e pertencentes ao mundo comum. Amar o mundo é a responsabilidade que passa de mão para mão, de boca em boca, construída pelas experiências humanas entre as gerações. Esse amor revela-se na amizade que cria laços entre as gerações. Através dessa amizade, os estudantes podem encontrar seu lugar de pertença no mundo, criado no tempo pelos vínculos entre os seres humanos, por meio da educação. Segundo analisa Almeida:

\footnotetext{
${ }^{57}$ Hannah Arendt, Entre o passado e o futuro, 2011, p. 247.
} 
Arendt poderia dizer que o amor mundi é a nossa opção de pertencer ao mundo - ao que acrescentaria que hoje essa pertença deixou de ser uma simples escolha e tornou-se muito mais uma questão e um desafio. $\mathrm{Na}$ pertença ao mundo também reside o principal desafio da educação hoje. Como fazer com que os novos se sintam em casa no mundo?58

Pensar a amizade para o campo da educação constitui um ato de reconciliação: modo de criar a amizade entre gerações na educação. A compreensão da amizade, que atravessa a temporalidade do mundo comum, estabelece e descobre novas configurações com o passado. Voltar ao passado significa pescar pérolas. Reencontrar esse tesouro esquecido, as histórias ainda não contadas, evidencia a responsabilidade de contá-las às novas gerações. $\mathrm{Na}$ durabilidade do mundo, construído por diversas gerações que aqui aportaram, herdou-se o legado histórico, cultural e político através da imortalidade de ações e feitos. Se a educação é a introdução de cada nova geração no mundo comum, uma amizade se faz necessária para que a geração recém-chegada se reconheça como parte desse mundo e, futuramente, se sinta responsável em cuidar desse legado.

Ouvir histórias é uma forma de dialogar e pensar junto às gerações antepassadas, compreender seus valores, suas vivências e as experiências que constituíram esse mundo compartilhado. A educação transmite e preserva o passado em suas histórias, indica onde se encontram os tesouros das experiências humanas, apresentando o seu valor às crianças e aos jovens. A educação cria novos laços de amizade entre as gerações. A amizade aparece no mundo através de uma relação de confiabilidade entre a geração mais nova (herdeira da história do mundo comum) e a geração mais velha (que tem autoridade de contar as experiências humanas duráveis no tempo). Essa relação entre as gerações que envolve a autoridade e a educação implica laços de amizade duráveis no tempo. Assim, expõe Carvalho:

Portanto, a autoridade - condição da possibilidade da transmissão intergeracional - vincula-se às formas pelas quais uma cultura dialoga com seus antepassados e com seus sucessores. É, pois, o caráter

${ }^{58}$ Vanessa Almeida, Educação em Hannah Arendt: Entre o mundo deserto e o amor ao mundo, 2011, p. 80. 
transcendente do mundo público - e a consequente assunção da responsabilidade pela durabilidade de uma herança comum de realizações simbólicas - que autoriza o lugar do educador na relação pedagógica. Um lugar sempre sujeito ao frágil equilíbrio entre o legado do passado e a abertura ao futuro, um lugar sempre instável em face da variedade de experiências históricas que fazem da autoridade um elo entre os educandos e um mundo de heranças e promessas. ${ }^{59}$

Através das histórias torna-se possível aos novos compreender o mundo habitado por várias gerações com as quais há a potencialidade de se tornar amigo e com elas aprender. Na educação, quando os novos são introduzidos no mundo comum, são criadas novas amizades. Ao se estabelecer uma relação entre a compreensão e a amizade na educação, as crianças e os jovens podem perceber que há diferenças entre as formas de ser e pensar entre culturas diversas. A diversidade faz parte de uma construção temporal humana na qual todos estão inseridos. As histórias marcam esse diálogo no tempo, afinal o que seriam dos amigos que não pudessem conviver e compartilhar suas experiências? A educação guarda sempre essa aposta na responsabilidade atribuída a uma geração futura, que assumirá o compromisso com o mundo, possibilitado pelo amor ao mundo.

Os estudantes, herdeiros de um mundo, são capazes de reconhecer e estabelecer conexões de amizade, encontrando o passado nas histórias contadas de geração para geração. A amizade na educação compreende um modo de ser e pensar, perdura no tempo humano, não perece com a morte. Quando o professor conta histórias do mundo, ele apresenta aos novos as vozes do passado e os laços de uma amizade entre as gerações são estabelecidos. Na educação, introduzimos os novos nesse diálogo com os antepassados, mediante a apresentação de um mundo comum. Com as histórias, gerações passadas revelam-se ao presente, mostrando suas ações em palavras, dizendo quem são. Com a amizade, os antepassados oferecem-se em amizade às novas gerações, que fazem uma escolha quando se sentem afetadas por aquelas experiências.

59 José Sérgio Fonseca de Carvalho, Educação, uma herança sem testamento: diálogos com o pensamento de Hannah Arendt, 2017, p. 66. 
A pluralidade encontrada nas experiências humanas de diversas gerações surge no mundo com a amizade. Quando as pessoas, cada uma com sua singularidade, reúnem-se através de vínculos de amizade, devido a um fim em comum, tornam-se amigas na constituição de um mundo. Espaço de educação, a escola cuida da singularidade de cada criança e jovem, tornando-se um local da presença da pluralidade das gerações que construíram esse mundo, sendo possível ouvir, compreender e pensar junto com elas. Com a educação, uma geração solidariza-se com a outra, em uma temporalidade, aprendendo sobre o mundo e reconhecendo-se como seu habitante. Segundo expõe Bárcena: "a educação implica um vínculo com a temporalidade do mundo humano; que ela não se desenvolve a partir de um vazio histórico, mas de uma experiência entre gerações que ocupam lugares distintos no mundo".60 A educação, desse modo, cria laços de amizade entre as gerações na temporalidade do mundo humano. Assim, as crianças e os jovens podem conhecer amigos de muito tempo que viveram em outras épocas, através de suas ações e palavras. Mesmo que os estudantes ainda não conheçam esses amigos, poderão conhecê-los através das histórias que os professores contam.

A amizade consolida a temporalidade de uma relação de convivência no mundo comum entre os seres humanos. Na medida em que decidimos contar as histórias sobre o que é relevante, relembrando as experiências humanas, traçamos um possível caminho para a amizade. A narrativa por histórias convida para um laço de amizade no tempo entre aqueles com quem se deseja compartilhar a própria história. Com as histórias há a reconciliação, que atravessa uma compreensão do passado e é permanente com o acolhimento da singularidade de cada ser humano frente à pluralidade no mundo.

Na educação, as histórias garantem tanto a transmissão de percepções forjadas no passado das gerações mais antigas, representadas pelos professores, quanto permitem a possibilidade de as novas gerações criarem suas próprias

60 Fernando Bárcena apud José Sérgio Fonseca de Carvalho, Educação, uma herança sem testamento: diálogos com o pensamento de Hannah Arendt, 2017, p. 63. 
histórias, assim como o professor August Halm contou histórias ao jovem Walter Benjamin, para que este pudesse se apropriar do mundo em suas mais diversas experiências. De igual maneira, ao contar suas histórias, Hannah Arendt legou ao mundo um gesto de amizade, através de um poema:

\author{
Há uns que nos falam e não ouvimos; \\ há uns que nos tocam e não sentimos; \\ há aqueles que nos ferem e \\ nem cicatrizes deixam, mas... \\ há aqueles que simplesmente \\ vivem e nos marcam por toda vida. ${ }^{61}$
}

\title{
Considerações finais
}

$\mathrm{O}$ ato de contar histórias em que os seres humanos se ligam ao mundo comum também é um elemento essencial de decisão sobre que mundo se deseja conservar e construir em conjunto. Narrar e estabelecer vínculos com os outros, por meio de laços de amizade, são condições essenciais não apenas para que se possa pensar, mas decidir sobre com quais seres humanos se quer criar um mundo comum. Assim, lembra Arendt que

\begin{abstract}
as nossas decisões sobre o certo e o errado vão depender de nossa escolha da companhia, daqueles com quem desejamos passar a nossa vida. Uma vez mais, essa companhia é escolhida ao pensarmos em exemplos, em exemplos de pessoas mortas ou vivas, reais ou fictícias, e em exemplos de incidentes passados ou presentes. No caso improvável de que alguém venha nos dizer que preferiria o Barba Azul por companhia, tomando-o assim como seu exemplo, a única coisa que poderíamos fazer é nos assegurarmos de que ele jamais chegasse perto de nós. ${ }^{62}$
\end{abstract}

Querer compartilhar o mundo é formar laços de amizade. A amizade está relacionada com a escolha, partindo de nossa relação pessoal com o mundo. Um jovem estudante pode perguntar-se: quem são essas pessoas e quais foram as suas

\footnotetext{
${ }^{61}$ Hannah Arendt apud Odílio Aguiar \& Roseane Mariano. A poesia de Hannah Arendt, 2013.

${ }^{62}$ Hannah Arendt. Responsabilidade e julgamento, 2004, p. 212.
} 
experiências que compuseram as histórias de um mundo comum? Para escolher os nossos amigos é indispensável uma educação que abra o caminho da compreensão. Os jovens terão de assumir futuramente as implicações e responsabilidades das escolhas que fizerem sobre eles mesmos e sobre o mundo, criado por gerações anteriores.

Os estudantes precisam saber da existência de Marielle Franco, Riobaldo e Nathan. Também precisam conhecer o totalitarismo, Hermogenes e o Barba Azul, para que tais histórias não se perpetuem. Através das histórias imortalizase a existência humana no mundo, compartilhada com os outros, sejam eles personagens de histórias ou da história ou pessoas da convivência cotidiana.

A amizade estabelece uma conexão entre os atos e palavras, entre as gerações e suas relações no tempo dentro de um mundo comum. A escolha de com quem se quer ser amigo implica lembrar ou esquecer o passado das gerações anteriores que legaram a possibilidade de reconciliação, mesmo após o fim da tradição. Portanto, ao estabelecer laços de amizades com o passado, cada nova geração poderá também deixar sua marca sobre o mundo comum.

\section{Referências}

AGUIAR, Odílio Alves. A amizade como amor mundi em Hannah Arendt. In: O que nos faz pensar, [S.1.], v. 19, n. 28, p. 131-144, dezembro 2010. ISSN 0104-6675.

AGUIAR, O. \& MARIANO, R. A poesia de Hannah Arendt. Artefilosofia, Ouro Preto, n.15, p. 119-132, dezembro 2013. ISSN: 2526-7892.

ALMEIDA, Vanessa Sievers de. Educação em Hannah Arendt: Entre o mundo deserto e o amor ao mundo. São Paulo: Cortez, 2011.

ARENDT, Hannah. A condição humana. $13^{\mathrm{a}}$ ed. Trad. Roberto Raposo. Rio de Janeiro: Forense Universitária, 2016a. 
. A vida do espírito. Tradução Abranches Almeida e Martins. $5^{\mathrm{a}}$ ed. Rio de Janeiro: Civilização Brasileira, 2016b.

A dignidade na política. Tradução de Helena Martins. Rio de Janeiro: Relume-Dumará, 2006.

.Compreender: formação, exílio e totalitarismo. Tradução Denise Bottmann.

1. ed. São Paulo: Companhia das letras; Belo Horizonte: Editora UFMG, 2007.

. Entre o passado e o futuro. 6. ed. Trad. Mauro W. Barbosa. São Paulo: Perspectiva, 2011.

. Homens em tempos sombrios. Trad. Denise Bottmann. São Paulo: Companhia das Letras, 2015.

. Responsabilidade e julgamento. São Paulo: Companhia das Letras, 2004.

. Sobre Hannah Arendt. Revista Inquietude, vol. 1, n 2, p. 123-163, ago/dez, 2010.

. Homens em tempos sombrios. Trad. Denise Bottmann. São Paulo: Companhia das Letras, 2015.

BENJAMIN, Walter. A hora das crianças: narrativas radiofônicas de Walter Benjamin. Tradução Aldo Medeiros. Rio de janeiro: Editora Nau, 2015.

CANDIDO, Antônio. Tese e antítese: ensaios. 4 ed. São Paulo: T.A. Queiroz, 2000.

CARVALHO, José Sérgio Fonseca. Reflexões sobre a educação, formação e esfera pública. Porto Alegre: Penso, 2013.

. Educação, uma herança sem testamento: diálogos com o pensamento de Hannah Arendt. São Paulo: Perspectiva, 2017.

HEUER, Wolfgang. Amizade política pelo cuidado com o mundo. In: História: Questões \& Debates, Curitiba, Editora UFPR, n. 46, p. 91-109, 2007. 
LAÉRTIO, Diôgenes. Vidas e Doutrinas dos Filósofos Ilustres. Tradução: Mário da Gama Kury. Brasília: Ed. UnB, 2008.

LESSING, Gotthold Ephraim. Três peças. Tradução Marcelo Backes. São Paulo: Topbooks, 2015.

PLATÃO. Apologia de Sócrates. In: Os Pensadores. São Paulo: Editora Abril, 1972. Hípias Maior. Trad. de Carlos Alberto Nunes. Editora da Universidade Federal do Pará. 1980.

ROSA, João Guimarães. Grande Sertão: Veredas. Rio de Janeiro: Editora Nova Fronteira, 2001.

STARLING, Heloísa. A outra margem da narrativa: Hannah Arendt e João Guimarães Rosa. In: Hannah Arendt: diálogos, reflexões, memórias. (Org.) Eduardo Jardim, Newton Bignotto. Belo Horizonte: Ed. UFMG, 2001.

YOUNG-BRUEHL, Elizabeth. Hannah Arendt, por amor ao mundo. Rio de Janeiro: Relume-Dumará, 1997.

Referência para citação deste artigo NASCIMENTO, C. Hannah Arendt \& João Guimarães Rosa: Reflexões sobre a amizade e a educação, Revista PHILIA | Filosofia, Literatura \& Arte. Porto Alegre, volume 1, número 1, 2 - 29, fevereiro de 2019. 